Dzieje Najnowsze, Rocznik LIII - 2021, 2

PL ISSN 0419-8824

Ireneusz Piotr Maj

https://orcid.org/0000-0001-8684-0374

Wydział Studiów Międzynarodowych i Politycznych Uniwersytetu Jagiellońskiego

Joanna Maj

https://orcid.org/0000-0002-0295-9245

Wydział Filozoficzno-Historyczny Uniwersytetu Łódzkiego

\title{
Geopolityczny imperatyw współpracy polsko-ukraińskiej w myśli politycznej ruchu prometejskiego na przykładzie publicystyki Włodzimierza Bączkowskiego*
}

\begin{abstract}
Abstrakt: Głównym celem poznawczym opracowania jest dokonanie analizy problemowej myśli politycznej Włodzimierza Bączkowskiego. Na poziomie konkretnym - w odniesieniu do tematyki publikacji - autorzy skupili się na propagowanej przez redaktora „Biuletynu Polsko-Ukraińskiego" koncepcji regionalnego systemu bezpieczeństwa oraz geopolitycznych uwarunkowaniach współpracy polsko-ukraińskiej wyodrębnionych z programu politycznego ruchu prometejskiego.
\end{abstract}

Słowa kluczowe: myśl polityczna, ruch prometejski, bezpieczeństwo międzynarodowe, geopolityka, polityka wschodnia.

Abstract: The main cognitive aim of the study is to conduct a problem analysis of Włodzimierz Bacczkowski's political thought. On a concrete level, in relation to the main subject of the publication, the author focused on the concept of a regional security system promoted by the editor of the Biuletyn Polsko-Ukrainski (Polish-Ukrainian Bulletin) and the geopolitical conditions of Polish-Ukrainian cooperation extracted from the political programme of the Promethean movement.

Keywords: political thought, Promethean movement, international security, geopolitics, eastern policy.

\footnotetext{
* Autorzy analizując myśl polityczną Włodzimierza Baczkowskiego, skupili się na publicystyce zamieszczonej na łamach „Biuletynu Polsko-Ukraińskiego” z lat 1932-1935.
} 


\section{Wprowadzenie}

Koncepcje bezpieczeństwa państwa, nakreślone przez doktrynerów obozu piłsudczykowskiego, nierozerwalnie wiązały się z założeniami ideologicznymi polskiej polityki zagranicznej. Strategiczna w wariancie maksymalistycznym i romantyczna w powszechnym odbiorze wizja walki „o naszą i Wasza wolność" funkcjonowała w myśli politycznej tej formacji, by zapewnić Polsce w przyszłości bezpieczeństwo od Wschodu ${ }^{1}$. W obliczu fiaska planów federacyjnych i międzymorza to ruchowi prometejskiemu - jako „pogrobowcowi” poprzednich założeń politycznych - miała przypaść rola spoiwa łączącego II Rzeczpospolita z tradycja wieloetnicznej Polski jagiellońskiej². W aspekcie międzynarodowym zasadniczym celem obozu sanacyjnego winno być zrealizowanie postulatu nowej regionalnej konfiguracji geopolitycznej. Jej istotna cechę stanowiły suwerenne państwa narodowe powstałe na gruzach imperialnej Rosji, połączone sojuszem z Polską ${ }^{3}$.

Założeniem ideologicznym prometeizmu była współpraca polityczna z mniejszościami narodowymi i etnicznymi dawnej Rosji, skierowana przeciwko polityce imperialnej ZSRR. Myśl prometejska - propagująca koncepcję podziału Imperium Rosyjskiego w oparciu o „porozumienie narodów uciśnionych Europy Wschodniej i Azji” - znajdowała swój wyraz w piśmiennictwie międzywojniaª

${ }^{1}$ Rozważania na temat myśli prometejskiej odnajdziemy w publikacjach prof. Zaura Gasimova. Por. Z. Gasimov, Między Warszawa, Paryżem a Stambutem. Myśl o prometeizmie $w$ ideowej przestrzeni międzywojennej Europy, w: Ruch prometejski i walka o przebudowe Europy Wschodniej (1918-1940). Studia i szkice, red. M. Kornat, Warszawa 2012, s. 331-333; I.P. Maj, Zagadnienie Kresów Wschodnich w myśli politycznej Włodzimierza Baczkowskiego, w: Państwo Niepodległe. Twórcy - strategie - komunikacja społeczna, red. A. Dawidowicz, E. Maj, Lublin 2019, s. 31-49.

2 R. Torzecki, Kwestia ukraińska w Polsce w latach 1923-1929, Kraków 1989, s. 172.

${ }^{3}$ Jak dotąd, oprócz monografii Sergiusza Mikulicza (S. Mikulicz, Prometeizm $w$ polityce II Rzeczypospolitej, Warszawa 1971), nie ukazało się pełne, rodzime opracowanie ruchu prometejskiego. Na uwagę zasługuje publikacja źródłowa Pawła Libery, opatrzona wstępem poświęconym historii ruchu prometejskiego: II Rzeczpospolita wobec ruchu prometejskiego, oprac. P. Libera, Warszawa 2013. Zagadnieniom prometejskim w aspekcie rywalizacji polsko-sowieckiej na polu ukraińskim poświęcona jest monografia Jana Jacka Bruskiego: J.J. Bruski, Między prometeizmem a Realpolitik. II Rzeczpospolita wobec Ukrainy sowieckiej 1921-1926, Kraków 2010. Szerokie spektrum publicystyki historycznej dotyczącej prometeizmu odnajdziemy na kartach czasopisma „Nowy Prometeusz”, wydawanego od grudnia 2010 r. (numer sygnalny 0/2000) przez Studium Europy Wschodniej Uniwersytetu Warszawskiego.

${ }^{4}$ Część historyków postrzega ideę prometejską jako mało realna, utopijną która powinna być rozpatrywana jedynie w charakterze „marzeń o wolnościowym posłannictwie Polski na terenach dawnego imperium carów”. Por. G. Zackiewicz, Polska myśl polityczna wobec systemu radzieckiego 1918-1939, Kraków 2004, s. 191-192, 352-354, 601-602. Ad vocem warto przytoczyć opinie Bruskiego, który porównywał prometeizm do „długoterminowej polisy ubezpieczeniowej na wypadek pożądanej, lecz daleko nie pewnej, implozji sowieckiego imperializmu”. J.J. Bruski, op. cit., s. 347. 
Wśród autorów opracowań o tematyce prometejskiej można wymienić zarówno publicystów polskich, jak i przedstawicieli emigracji politycznej oraz mniejszości narodowych, w tym także Ukraińców ${ }^{5}$. W idei prometejskiej - oprócz narzędzia w egzekwowaniu prawa do samostanowienia narodów - upatrywali oni gwarancji wzmocnienia pozycji międzynarodowej oraz szansy na rozbicie sojuszu sowiecko-niemieckiego. W tym samym duchu wypowiadał się publicysta piłsudczykowski, sowietolog, redaktor organu prasowego myśli prometejskiej „Biuletynu Polsko-Ukraińskiego” - Włodzimierz Bączkowskí.

\section{Materialne aspekty oddziaływania geopolitycznego}

Uwidoczniony w poglądach Bączkowskiego ${ }^{7}$ prymat interesów państwa uwarunkowany był zarówno położeniem geopolitycznym, jak i wytworzona w kręgu tej problematyki „mesjanistyczną myślą narodową”. Problem

${ }^{5}$ Publicystyką na łamach czasopism prometejskich zajmowali się m.in.: Mykoła Kowałewski, Bohdan Łepki, Jewhen Małaniuk, Iwan Kedryn-Rudnicki, Roman Smal-Stocki, Konstanty Symonolewicz jr, Pawło Wasynczuk.

${ }^{6}$ A. Chojnowski, Koncepcje polityki narodowościowej rzqdów polskich w latach 1921-1939, Wrocław 1979, s. 185-186; J. Cisek, Tylko razem. Wtodzimierz Baczkowski $i$ „Biuletyn Polsko-Ukraiński”, „Biuletyn Instytutu Pamięci Narodowej” 2008, nr 5/6 (88-89), s. 76-83; F. Gończyński-Jussis, Biuletyn Polsko-Ukraiński (1932-1938) - prometejski projekt Oddziału II Sztabu Głównego Wojska Polskiego, w: Na z góry upatrzonych pozycjach, red. B. Międzybrodzki, M. Gajda, K. Fudalej, M. Przeperski, Warszawa 2011, s. 281-290; P. Libera, Biuletyn Polsko-Ukraiński (1932-1938) pismo programowe ruchu prometejskiego, „Київські полоністичні студіï” 2011, t. XVIII, s. 33-41; I.P. Maj, Działalność Instytutu Wschodniego $w$ Warszawie 1926-1939, Warszawa 2007, s. 113, 144-146.

7 Włodzimierz Bączkowski (1905-2000), publicysta, sowietolog, działacz prometejski, urodzony na stacji kolejowej Bajkał, pracownik Instytutu Wschodniego w Warszawie, współzałożyciel Orientalistycznego Koła Młodych, redaktor „Wschodu”, „Biuletynu Polsko-Ukraińskiego”, „Problemów Europy Wschodniej”, pracownik Oddziału II Sztabu Głównego Wojska Polskiego. Maszynopis życiorysu Baczkowskiego znajduje się w zasobie archiwalnym Instytutu Józefa Piłsudskiego w Ameryce: Instytut Józefa Piłsudskiego w Ameryce, Archiwum Włodzimierza Baczkowskiego 1912-1996, Zespół Archiwalny nr 132, Inwentarz nr 1: Dokumenty osobiste korespondencja, fotografie, kopie dyplomów, k. 1-100. Por. J. Giedroyć, Wtodzimierz Baczkowski, „Eurazja” 1997, nr 1, s. 89; J. Cisek, Świadectwa, „Eurazja” 1997, nr 1, s. 90-91; W. Bączkowski, O wschodnich problemach Polski. Wybór pism, oprac. J. Kloczkowski, P. Kowal, Kraków 2000, s. 7-28; P. Libera, Włodzimierz Baczkowski i jego wspótpraca z paryska „Kultura”, w: Giedroyc a Ukraina. Ukrainska perspektywa Jerzego Giedroycia i środowiska paryskiej „Kultury”, red. M. Semczyszyn, M. Zajączkowski, Warszawa-LublinSzczecin 2014, s. 104-121; I.P. Maj, op. cit., s. 154-159, 163-165, 173.

8 Spośród literatury poświęconej badaniom nad myślą polityczną Włodzimierza Bączkowskiego należy wymienić następujące publikacje: P. Eberhardt, Twórcy polskiej geopolityki, Kraków 2006, s. 187-201; J. Kloczkowski, Jak rozwiqzać spór polsko-ukraiński? Publicystyka Włodzimierza Baczkowskiego z lat trzydziestych, w: Narody i historia, red. A. Rzegocki, Kraków 2000, s. 207-238; B. Rutkowski, Wtodzimierz Baczkowski - publicysta, „Nowy 
geopolitycznego usytuowania kraju rozpatrywał w dwóch obszarach: materialnym, odnoszącym się do kształtu politycznego tej części Europy oraz emocjonalnym, czyli subiektywnym charakterze duchowości i kulturowości polskiej. Współistnienie tych imponderabiliów miało gwarantować trwały, oparty na programie politycznym, fundament bezpieczeństwa narodowego „zdrowej racji stanu”.

W aspekcie materialnego oddziaływania na politykę wschodnią uwypuklał Bączkowski problemat zagrożenia niemiecko-rosyjskiego. Na tym tle kluczowe znaczenie przypisywał „gwałtownej” - jak to określał - rywalizacji polsko-niemieckiej. Naznaczone stałością i strukturalnością rewizjonistycznych zapędów Stalina względem postanowień pokoju ryskiego były również relacje polsko-sowieckie. Rozpatrując hipotetycznie - aczkolwiek wyjątkowo trafnie - treść dodatkowej klauzuli dopełniającej ustalenia rapalskie, przestrzegał przed niemiecko-sowieckim zbliżeniem politycznym „wymierzonym bezpośrednio w niezależny byt państwa polskiego”. Niemcy - jak zauważył „żądają od Polski terytoriów Śląska, Wielkopolski i Pomorza Gdańskiego, ZSRR - podporządkowania się ich polityce imperialnej”. Przeciwwagi dla wrogiego bloku, złożonego z Niemiec, Włoch i ZSRR, upatrywał w sojuszu z Francją i Rumunią. Zaznaczał jednocześnie, że zakładana tym samym względna równowaga polityczna może ulec zachwianiu na skutek wzmocnienia Sowietów sojuszem ze Stanami Zjednoczonymi. Mógłby on zmaterializować się w obliczu konfliktu z Japonią spowodowanego rywalizacją o wpływy w Azji Południowo-Wschodniej. Wprawdzie rywalizacja radziecko-japońska miała sprzyjać sprawie polskiej, jednakże kwestia japońska, w przypadku wojny polsko-radzieckiej, mogłaby nie wykroczyć poza ramy neutralności. Niekorzystny ogląd sytuacji międzynarodowej pogłębiało - nabrzmiałe falą rewizjonizmu wersalskiego - zagrożenie powiększenia orbity wpływów niemieckich o Węgry i Bułgarię ${ }^{10}$.

Przewaga bloku sowiecko-niemieckiego - zdaniem redaktora „Biuletynu Polsko-Ukraińskiego" - objawiała się w wielu czynnikach: demograficznym, terytorialnym i ekonomicznym (surowcowym). W każdym z tych aspektów sojusznicy Polski ustępowali jej sasiadom. Czas działał na korzyść Niemiec i ZSRR, które odbudowywały potencjał militarny i podporządkowywały sobie - szczególnie Sowieci - „wychowaną w ascetyzmie i niewoli ludność”. Skrystalizowane granice Europy Zachodniej, uśpionej skutkami ostatniej wojny

Prometeusz", IV 2015, nr 7, s. 93-101. Myśl polityczna Bączkowskiego została wykorzystana w monografii obozu piłsudczykowskiego autorstwa Waldemara Parucha: W. Paruch, Myśl polityczna obozu pitsudczykowskiego, Lublin 2005.

9 W. Bączkowski, Na marginesie prób tworzenia polskiej racji stanu w kwestii ukraińskiej, „Biuletyn Polsko-Ukraiński” R. I, 1932, nr 1, s. 8-13; R. Torzecki, op. cit., s. 168.

${ }^{10}$ W. Bączkowski, Rozważania teoretyczne na temat kwestii ukraińskiej i Polski współczesnej. Cz. 2, „Biuletyn Polsko-Ukraiński” R. II, V 1933, nr 4 (6), s. 25-29. Por. P. Eberhardt, op. cit., s. 189. 
światowej, nie powstrzymaja - zdaniem Bączkowskiego - „dochodzących do przedwojennego stanu psychicznego Niemiec"11.

Szansy dla wzmocnienia systemu bezpieczeństwa regionalnego upatrywał w możliwości zaistnienia w Europie Środkowej „związku państw małych”. Polska, Francja i Rumunia mogły jego zdaniem liczyć na wsparcie tzw. Małej Ententy. Antysowiecki blok powinna wesprzeć Wielka Brytania. Podawał tym samym w wątpliwość zaangażowanie Brytyjczyków w obronę polskiej racji stanu. Nadziei na osłabienie wektora sowieckiej ekspansji upatrywał bezkrytycznie $\mathrm{w}$ ustaleniach paktu o nieagresji z ZSRR i zbrojnym zaangażowaniu tego państwa na Dalekim Wschodzie (spór z Japonią o Mandżurię). Wnioski słaniały go do przekonania o powstaniu „idealnego sojuszu niemiecko-sowieckiego" skierowanego przeciwko przymierzu polsko-francuskiemu. Za takim scenariuszem wydarzeń przemawiały względy strategiczne i działania o charakterze militarnym - zlokalizowanie zgrupowań sił zbrojnych Armii Czerwonej i Reichswehry przy granicy z Polską czy też budowa francuskich fortyfikacji zw. Linią Maginota ${ }^{12}$.

Względy bezpieczeństwa zewnętrznego nierozerwalnie łączył Bączkowski z koniecznościa zapewnienia stabilizacji wewnętrznej kraju. Istotniejszym zagrożeniem była jego zdaniem niestabilna sytuacja polityczna na wschodzie, na którą miały wpływ: „przemieszanie granic politycznych z narodowo-etnograficznymi i wojowniczo-zaborczy imperializm ZSRR”. Wieloetniczność powstałego na drodze podbojów narodów ościennych państwa Stalina otwierała nowe możliwości wykorzystania czynników odśrodkowych. Podkreślał, że polska racja stanu nie wiązała się z ekspansją terytorialną na wschodzie, gdyż nie posiadaliśmy możliwości ,absorbcji państwowej terenów zamieszkałych przez ludność niepolską. W tej sytuacji bezpieczeństwo naszych granic miał zapewnić „sojusz z narodami zniewolonymi”" ${ }^{13}$.

\section{Ukraina w kręgu polskiej mesjanistycznej myśli narodowej}

Bączkowski w idei prometejskiej upatrywał narzędzia w egzekwowaniu prawa do samostanowienia narodów. Prometeizm stanowił kluczowy element mesjanistycznej wizji wytworzonej w obrębie obozu władzy, predestynującej Polskę do pełnienia wyjątkowej roli w polityce zagranicznej. Miał gwarantować wzmocnienie pozycji międzynarodowej, rozbicie sojuszu sowiecko-niemieckiego i odcięcie Niemiec od radzieckich złóż surowców. Narody zniewolone przez

\footnotetext{
11 W. Baczkowski, Na marginesie..., s. 8-13. Por. J.J. Bruski, op. cit., s. 80-81.

12 W. Bączkowski, Rozważania [...] Cz. 2..., s. 25-29. Por. W. Materski, Na widecie. II Rzeczpospolita wobec Sowietów 1918-1943, Warszawa 2005, s. 392-393; G. Zackiewicz, op. cit., s. 355-356.

${ }^{13}$ W. Bączkowski, Na marginesie..., s. 8-13.
} 
ZSRR, realizując ideę „frontu prometejskiego”, stanowiły „siłę działająca w terenie, mogacą zmienić oblicze Europy Wschodniej" ${ }^{14}$.

Ukształtowana w duchu prometeizmu działalność ideotwórcza Bączkowskiego opierała się na przeświadczeniu, że „głównym kluczem do rozwiązania zagadnienia, zasadniczym elementem całego frontu, mogacym przekształcić układ sił jest Ukraina. Jej suwerenność warunkuje poza tym w dużej mierze możliwości niepodległościowe dla Kaukazu, zasilającego organizm ZSRR swoimi bogactwami" ${ }^{15}$.

Był przekonany, że zbudowana na przesłankach dyferencjacji Sowietów na państwa narodowe idea wolnej Ukrainy zostanie zmaterializowana w nowy podmiot międzynarodowego systemu bezpieczeństwa, który „przejmie na siebie połowę ciężaru imperializmu rosyjskiego”. Jak słusznie zauważał - jeszcze w realiach początku lat trzydziestych - jeżeli nawet Rosja „w warunkach depresji” jest w stanie uznać suwerenność Polski, państw bałtyckich, straty terytorialne na rzecz Japonii, to Kreml „nigdy nie pogodzi się z odpadnięciem Ukrainy, utraceniem brzegów Morza Czarnego, Krymu, kraju, który dostarcza około 75\% całej sowieckiej produkcji żelaza, 98\% antracytu, z utrata Zagłębia Donieckiego itd.” Obrona polskiego i ukraińskiego stanu posiadania była możliwa dzięki obopólnemu porozumieniu politycznemu i współpracy gospodarczej opartej na obszarze czarnomorsko-bałtyckim ${ }^{16}$.

W niepodległości Ukrainy upatrywał więc Bączkowski „rację stanu i obowiązek państwa polskiego". Jednakże - co podkreślał - istotniejszym niż wywalczenie niepodległości problemem była zdolność utrwalenia suwerenności. Wskazywał na to - jego zdaniem - upadek państwowości ukraińskiej w korzystnych dla jej utrzymania okolicznościach koniunktury międzynarodowej: „Zdawało się, że potrzeba większego wysiłku do osiagnięcia upadku władzy zaborczej, a wszystko inne będzie dodane. Życie wykazało stan rzeczy wręcz odmienny. Łatwiej było zdobyć niepodległość, niż ją utrzymać". Przyczyn takiego stanu rzeczy upatrywał Bączkowski w sporach wewnętrznych, stosunku Ukraińców do mniejszości etnicznych na terenie Doniecka, Kubania i Krymu i nasuwających się w związku z tym kwestii granicznych. Jak podkreślał: „kwestia ukraińska w swym aspekcie niepodległościowym, to jednocześnie kwestia właściwych stosunków głównie polsko-ukraińskich i ukraińsko-rosyjskich" ${ }^{17}$.

Nadanie kierunkowi ukraińskiemu znaczenia priorytetowego dla bezpieczeństwa państwa powinno wpłynąć pozytywnie na stosunek władz państwowych do mniejszości ukraińskiej. Polska - w przeciwieństwie do Ukrainy - to

\footnotetext{
${ }^{14}$ Ibidem. Por. wstęp i zarys historyczny do wyboru źródeł: II Rzeczpospolita wobec ruchu prometejskiego..., s. 15-16; J.J. Bruski, op. cit., s. 10.

${ }^{15}$ W. Bączkowski, Rozważania [...] Cz. 2..., s. 25-29.

${ }^{16}$ Ibidem.

${ }^{17}$ Ibidem, s. 29.
} 
kraj suwerenny, samowystarczalny gospodarczo, jednakże zaakceptowanie ukraińskich postulatów niepodległościowych przez opinię publiczną uzależnione było od powiązania kwestii ukraińskiej - w znaczeniu terytorialnym - przede wszystkim z obszarem Ukraińskiej Socjalistycznej Republiki Radzieckiej $^{18}$. Kwestii rewizji granic II Rzeczypospolitej na rzecz przyszłego państwa ukraińskiego nie podejmowano oficjalnie na łamach „Biuletynu Polsko-Ukraińskiego". Wprawdzie redakcja odnosiła się pośrednio do tych zagadnień, publikując - potwierdzające potrzebę zainicjowania procesu niepodległościowego na Ukrainie - wyniki ankiet, jednakże natychmiastowa i zdecydowanie negatywna reakcja prasy endeckiej stanowiła odzwierciedlenie stanowiska większości społeczeństwa ${ }^{19}$. Zdając sobie sprawę z fasadowości postulatu autonomii Galicji Wschodniej, przychylano się do maksymalnego wówczas programu opartego na piemontyzacji narodowo-kulturowej Ukraińców czy też szwajcaryzacji stosunków narodowościowych w Polsce ${ }^{20}$.

\section{Geopolityczne uwarunkowania przyszłej współpracy polsko-ukraińskiej}

W tym aspekcie, nawiązując do wspólnoty interesów politycznych, podkreślał Bączkowski znaczenie „względnej identyczności położenia geopolitycznego obu narodów i niewchodzenia istotnych interesów państwowych polskich i ukraińskich w kolizję wzajemną" Dla potwierdzenia tej tezy wskazywał na nowe koncepcje ukraińskiego centrum „bytu narodowego i państwowego warunkującego wolność wraz z rozwojem własnej kultury i wyższym standardem życia narodu”. Odwołując się do myśli politycznej środowisk emigracyjnych skupionych wokół rządu Ukraińskiej Republiki Ludowej²1, przewidywał, że rolę takiego ośrodka przestaną pełnić Kijów i prawobrzeżna Ukraina. Przyszłość - jego

18 T. Hołówko, Minimalny program polityki polskiej we Wschodniej Galicji i na tzw. kresach, „Droga” 1924, nr 10, s. 3; R. Torzecki, op. cit., s. 132, 137; P. Eberhardt, op. cit., s. 188.

19 W. Bączkowski, Kolejny fatsz endecji, „Biuletyn Polsko-Ukraiński”, 17 XII 1933, nr 33, s. 1-3. Por. J.J. Bruski, op. cit., s. 26.

${ }^{20}$ Pozyskanie mniejszości dla koncepcji tworzenia narodu państwowego mogło być możliwe po zaspokojeniu - co podkreślał Bączkowski - ich słusznych postulatów. Zasadzały się one na autonomii terytorialnej Galicji Wschodniej, z sejmem i rządem krajowym, wyposażonym w prerogatywy na gruncie polityki gospodarczej, wyznaniowej i edukacji. Idem, Tadeusz Hołówko w kwestii ukraińskiej, „Biuletyn Polsko-Ukraiński” R. II, II 1933, nr 1 (3), s. 12-20; R. Torzecki, op. cit., s. 83; J.J. Bruski, op. cit., s. 325-326; A. Chojnowski, op. cit., s. 80-86; I. Werschler, Z dziejów obozu belwederskiego. Tadeusz Hołówko życie i działalność, Warszawa 1984, s. 187-196; T. Hołówko, Minimalny program..., s. 3; idem, Metody $i$ drogi sanacji stosunków we Wschodniej Galicji $i$ Województwach Wschodnich, „Droga” 1926, nr 6-7, s. 46-47.

${ }^{21}$ W. Sadowśkyj, [brak tytułu], „Tryzub”, 22 I 1933. Por. W. Bączkowski, Rozważania teoretyczne na temat kwestii ukraińskiej i Polski wspótczesnej, „Biuletyn Polsko-Ukraiński” R. II, IV 1933, nr 3 (5), s. 23-29. 
zdaniem - należeć będzie do „wielokąta tworzonego liniami - MarjupolŁugańsk-Charków-Odessa”. Szansę na przystapienie Ukrainy - „obok Francji i Włoch do grona narodów śródziemnomorskich" - stanowiła integralność terytorialna przyszłego państwa ukraińskiego z wybrzeżem czarnomorskim i zagłębiem donieckim. Bogactwa naturalne występujące na tych terenach miały zapewnić suwerennej Ukrainie zrównoważony wzrost gospodarczy. Wzmocnieniem argumentacji na rzecz przesunięcia ukraińskiego centrum narodowego na wschód była zdaniem Bączkowskiego naturalna tendencja do przemieszczania stref wpływów Słowian Zachodnich w kierunku wschodnim ${ }^{22}$.

W odróżnieniu od domniemanych ośrodków polityczno-gospodarczych przyszłej Ukrainy aortę polskiego życia narodowego lokalizował na zachodzie, wzdłuż linii: Pomorze-Warszawa-Śląsk. Jak podkreślał Bączkowski, wpływy centrów polskiego i ukraińskiego zachodzą na siebie „w części bardzo nieznacznej”. Peryferiami „o drugorzędnym znaczeniu państwowym” i gospodarczym określał tym razem Kresy Południowo-Wschodnie. Niepodległa Ukraina roztaczając swe wpływy na obszarze basenu czarnomorsko-bałtyckiego, miała przysporzyć Polsce przede wszystkim korzyści natury ekonomicznej i politycznej. Poddając analizie wzajemne zależności gospodarcze, podkreślał, że problem ich podziału na terenach przygranicznych - który np. istniał w relacjach polsko-niemieckich (Ślask) i rosyjsko-ukraińskich (Donbas) nie dotyczył pozbawionych większych ośrodków przemysłowych województw południowo-wschodnich ${ }^{23}$.

\section{Przyczyny kryzysu w relacjach polsko-ukraińskich}

Redaktor „Biuletynu Polsko-Ukraińskiego” ubolewał, że nową kartę w relacjach polsko-ukraińskich nadwyrężały skutki traktatu ryskiego i paktu o nieagresji z ZSRR ${ }^{24}$. Pomimo faktycznej intensyfikacji kontaktów polsko-sowieckich zauważalnych w latach 1932-1933, polemizował z tezami zawartymi w odezwach ugrupowań nacjonalistycznych. „Państwa podpisujące pakty z Sowietami - jak pisano - odmawiaja tym samym pomocy i protekcji narodom uciśnionym i przyczyniają się do akcji katowania Ukrainy". Autorzy tych proklamacji podkreślali ponadto ścisła zależność pomiędzy niepodległością Ukrainy a gwarancją bezpieczeństwa państw regionu, w tym przede wszystkim Polski ${ }^{25}$.

\footnotetext{
${ }^{22}$ Bączkowski wspominał o „ukraińskiej kolonizacji Kubania”. W. Bączkowski, Rozważania teoretyczne..., s. 29.

${ }^{23}$ R. Torzecki, op. cit., s. 136.

${ }^{24}$ J.J. Bruski, op. cit., s. 31-44; W. Materski, op. cit., s. 424-432.

25 Tekst odezwy Europejskiego Zjednoczenia Organizacji Ukraińskich na Obczyźnie zamieszczono w czasopiśmie „Nowyj Czas”, 16 VII 1933. W. Bączkowski, Trzy uwagi, „Biuletyn Polsko-Ukraiński” R. II, 23 VII 1933, nr 12, s. 7-8.
} 
Zdaniem Bączkowskiego za ich przesłaniem ideologicznym kryły się „siły politycznie, powiąane z kontrahentami traktatu w Rapallo, u których to dotąd mieli szukać pomocy i protekcji”. Uważał, że nacjonalistyczne koła ukraińskie - skupione wokół Jewhena Konowalca - świadomie nie podejmowały eksplikacji prosowieckiej polityki Niemiec ${ }^{26}$. Koncepcji filogermańskiej sprzyjać mieli również publicyści sympatyzujący z Ukraińską Organizacja Wojskowa (UWO), publikujacy w wydawanych za granica czasopismach „Surma” i „Rozbudowa Nacji”27. Zarzut wykorzystywania porozumienia polsko-radzieckiego do podżegania antypolskich nastrojów znalazł uzasadnienie w polemizującej z linią ideologiczna „Biuletynu Polsko-Ukraińskiego” publicystyce „Ukraińskiej Nywy” z Łucka. Bączkowski, czerpiąc przykłady z prasy ukraińskiej, krytykował autorów, którzy relatywizując skutki nieprzychylnych Polsce sojuszy, wypaczali prawdę historyczną zarzucając - na ten przykład - Józefowi Ignacemu Kraszewskiemu działalność szpiegowska na rzecz Francji i Włoch ${ }^{28}$. Przypisywał mu przy tym brak solidaryzmu z obozem władzy, który nie powinien mieć miejsca w obliczu antypolskiej propagandy płynącej z Kremla. Jak stwierdzał, „nie dopatrywano się zupełnie nic złego dla narodu ukraińskiego w ZSRR, a nawet owszem widziało w owej «bod szczo bud - urainśkij derżawi» nad Dnieprem postęp w kierunku narodowym" 29 .

Doceniając pozytywną reakcję przywódców emigracji politycznej oraz części kół ukraińskich, odcinających się od działalności terrorystycznej nacjonalistów $^{30}$, za nieuzasadnione uważał porównanie linii ideologicznej redagowanego przez siebie czasopisma ze skrajnie prawicowym białoruskim „Nowym Szlachem" ${ }^{31}$. Wspominał negująca polsko-ukraińskie pojednanie retorykę, którą na łamach redagowanego przez siebie pisma „Nowyj Czas” podejmował w następujących słowach Dmytro Palijew: „A jaką moralną i organizacyjna siłę reprezentuje UNDO? Tych 1000 lub 2000 formalnych członków, z warstwy inteligentów, w gronie których są i tacy, którzy reklamują monarchizm,

${ }^{26}$ W. Materski, op. cit., s. 414-419; R. Torzecki, op. cit., s. 367-368; K. Grünberg, B. Sprengel, Trudne sqsiedztwo. Stosunki polsko-ukraińskie $w X-X X$ wieku, Warszawa 2005, s. 354-355.

${ }^{27}$ E. Misiło, Prasa ukraińska w Polsce (1918-1939), „Kwartalnik Historii Prasy Polskiej” 1984, t. XXIII, nr 4, s. 76; E. Wiszka, Prasa emigracji ukraińskiej w Polsce 1920-1939, Toruń 2001, s. 98-102.

28 „Nowyj Czas”, 13 VII 1933. Por. W. Bączkowski, Trzy uwagi..., s. 7-8.

${ }^{29}$ W. Bączkowski, Trzy uwagi..., s. 7-8.

${ }^{30}$ Wystapienie sejmowe Dymitra Lewickiego z 3 XI 1932 r. Por. D. Lewicki, Na tle Gródka Jagiellońskiego, „Biuletyn Polsko-Ukraiński” R. I-II, 1932/1933, nr 2, s. 33; M. Szumiło, Ukrainska Reprezentacja Parlamentarna w Sejmie i Senacie RP (1928-1939), Warszawa 2007.

31 Propagowanie faszyzujących treści przypisywało się pismu „Nowy Szlach”, założonemu w 1933 r. przez pochodzącego z Sokólszczyzny Władysława Kozłowskiego. E. Mironowicz, Prasa białoruska pod okiem rosyjskiej i polskiej cenzury, „Białoruskie Zeszyty Historyczne” 1996, nr 1 (5), s. 74. 
inni są stałymi współpracownikami «Biuletynu Polsko-Ukraińskiego», a inni znowu współpracują w "Nowych Szlachach»"32.

Analizując poglądy Bączkowskiego dotyczące skutków sojuszu ukraińsko-niemieckiego, można odnieść wrażenie, że nacechowane były one brakiem spójności. Twierdził np., że - po pierwsze - porozumienie takie uniemożliwi dalsza współpracę Rzeszy z Sowietami, po wtóre - otworzy drogę do rozmów polsko-radzieckich w kwestii przyszłości Ukrainy. Nie brał pod uwagę zmiany koniunktury politycznej wywołanej konfliktem zbrojnym pomiędzy dawnymi sojusznikami oraz podsycania przez Niemcy czystek etnicznych na terenie Ukrainy ${ }^{33}$.

Do zagrożeń mających wpływ na stan bezpieczeństwa Polski na wschodnim pograniczu zaliczał Bączkowski nierozwiązaną kwestię narodowościowa i wzmożona aktywność nacjonalizmu integralnego. Taka polityka - będąc wodą na młyn propagandy kremlowskiej - sprzyjała destabilizowaniu sytuacji politycznej na Kresach poprzez wpieranie „niezaspokojonych dążeń narodowowyzwoleńczych” i obronę „uciśnionych mas pracujących Zachodniej Białorusi i Ukrainy”. Pomimo krytycznego ustosunkowania się do skrajnie prawicowego piśmiennictwa ukraińskiego Bączkowski podawał w wattpliwość celowość zastosowania rozwiązań siłowych wobec reprezentujących takie poglądy działaczy ukraińskich: „Nie argumentem rewolweru, bomby lub kija, lecz argumentem otwartego programu pracy, słowem, przekonaniem i wiara walczyć będziemy o realizację hasła zbliżenia polsko-ukraińskiego" ${ }^{34}$. Polityka represji, w jego mniemaniu, była „objawem słabości i porażki w poszukiwaniu rozwiązań problemu kresowego”. Sposobnością do zaprezentowania na łamach „Biuletynu Polsko-Ukraińskiego" ugodowego stanowiska w kwestii ukraińskiej stały się powszechnie komentowane wówczas wydarzenia w Gródku Jagiellońskim ${ }^{35}$. Bączkowski określając członków UWO: „Zaklętymi wrogami Polski, wykorzystujacymi młody, buńczuczny, skory do czynów nacjonalizm młodzieży ukraińskiej”, zarzucał kierownictwu tej organizacji „uleganie nieukraińskim postulatom, działalność samobójczą w swej ślepocie" ${ }^{36}$.

${ }^{32}$ D. Palijew, Ku likwidacji oszukaństwa, „Nowyj Czas”, 13 VII 1933. Por. W. Baczkowski, Trzy uwagi..., s. 7-8. Por. biogram Palijewa: https://bs.sejm.gov.pl/F?func=find=-b\&request000001172\&find_code=SYS\&local_base=ARS10 (dostęp: 23 IV 2019). Por. R. Torzecki, op. cit., s. $378-379$.

${ }^{33}$ Wstęp do numeru 1 pisma pod redakcją Bączkowskiego. Por. „Biuletyn Polsko-Ukraiński” R. I, IX-X 1932, nr 1, s. 2.

${ }^{34}$ W. Baczkowski, Na tle Gródka Jagiellońskiego..., s. 35.

${ }^{35}$ Ofiarami ataku terrorystycznego UWO padło pięciu pracowników gródeckiego urzędu pocztowego i funkcjonariuszy policji. W zamachu dokonanym niespełna półtora roku po śmierci Tadeusza Hołówki wzięli udział ci sami sprawcy: Dmytro Danyłyszyn, Wasyl Biłas i Marian Żurakowski. Ibidem, s. 33; „Gazeta Lwowska”, 2 XII 1932. Por. K. Szymański, Tajemnica śmierci Hołówki, „Kurier Galicyjski”, 31 VIII - 11 IX 2017, nr 16 (284), s. 26-27.

36 W. Bączkowski, Na tle Gródka Jagiellońskiego..., s. 33; R. Torzecki, op. cit., s. 132. Por. B. Hud, Ukraincy i Polacy na Naddnieprzu, Wotyniu i w Galicji Wschodniej $w$ XIX i pierwszej połowie XX wieku, tłum. A. Korzeniowska-Bihun, M. Hud, Warszawa 2018, s. 223-277. 
Analiza sytuacji narodowościowej, przeprowadzona przez Bączkowskiego na kanwie tych wydarzeń, nie jest jednostronna. Genezy sporu polsko-ukraińskiego nie upatrywał wyłącznie w zaszłościach historycznych. Postrzegał je przede wszystkim „w posunięciach politycznych przywódców narodu polskiego i ukraińskiego". Podkreślał przy tym, że credo problematyki narodowościowej w Polsce należało rozpatrywać na podstawie formalnego status quo położenia geopolitycznego. W jego mniemaniu czynnikiem destabilizującym relacje polsko-ukraińskie „sa Niemcy i ZSRR, posiadające wysoką kulturę rządzenia i organizacji, górujące pod tym względem nad Polakami i Ukraińcami”. Przychylając się do poglądów publicysty piłsudczykowskiego Olgierda Górki, uważał, że obóz władzy odsunął w przeszłość mentalność szlachecka na rzecz pragmatycznej oceny wzajemnych relacji, które należy budować na nowych zasadach, bez odnoszenia się do przeszłości ${ }^{37}$. Jednakże, w odróżnieniu od założeń ideologicznych, praktyka okazała się zgoła odmienna. Rządzący nadal utożsamiali mniejszości narodowe z wrogiem publicznym, a ich postulaty z ideami szkodliwymi dla Polski: „Całe rzesze młodzieży ukraińskiej, dzięki polskiej polityce narodowościowej, zostały usunięte poza nawias życia państwowego, nie posiadaja możności odpowiedniego wyładowania swej energii życiowej, zostały wepchnięte w getto własnego niezadowolenia i buntu przeciwko istniejącemu stanowi rzeczy”. Dalej pisał: „któż jak nie my sami ułatwiliśmy wrogowi zorganizować tą młodzież $\mathrm{w}$ posłuszne sobie narzędzie godzace $\mathrm{w}$ istocie swej $\mathrm{w}$ Jutro niepodległości ukraińskiej"38.

Popieranie dążeń niepodległościowych Ukraińców wypływało również z historycznej roli Polski, jej tradycji walki o wolność, czerpiącej swe siły witalne z polskiej myśli politycznej. „Historia - jak twierdził Bączkowski determinuje władze Rzeczpospolitej do odważnego wysiłku w kierunku należytego rozwiązania problematu niepolskich narodowości w Polsce". Wsparcie dla ruchów niepodległościowych narodów uciśnionych czyniło polską opinię publiczną uwrażliwioną na kwestię ukraińska. Jak pisał: „Problem niepodległej Ukrainy uznany jest (lecz czy konsekwentnie realizowany?) przez polską rację stanu, jako warunek umocnienia Polski”, dla zapewnienia bezpieczeństwa wynikającego z geopolitycznego położenia Polski i realizacji polskiej „misji na Wschodzie". Zdaniem Baczkowskiego zagadnienie to należy uwzględnić w polityce wewnętrznej. Ukraińcy powinni też zrozumieć polską politykę i przyjąć ją jako ,jedynie słuszna, dyktowana koniecznością ratowania swego narodu i wymogami walki o niepodległość" ${ }^{39}$.

${ }^{37}$ O. Górka, Dziejowa rzeczywistość a racja stanu Polski na Południowym Wschodzie, „Polityka Narodów" 1933, nr 1-2.

${ }^{38}$ W. Bączkowski, Na tle Gródka Jagiellońskiego..., s. 34. Por. W. Paruch, op. cit., s. 385-397.

${ }^{39}$ W. Bączkowski, Na marginesie..., s. 8-13. 


\section{Podsumowanie}

Program polityczny ruchu prometejskiego był możliwy do zrealizowania w warunkach zdecentralizowanej władzy wzmacniającej rolę samorządu terytorialnego. Sytuacja międzynarodowa przełomu dekad czyniła ten warunek nieosiagalnym. Niesprzyjające sprawie pojednania polsko-ukraińskiego okazały się postanowienia traktatów, w tym szczególnie tzw. małego traktatu wersalskiego. Ekspansja ideologii komunistycznej trafiała na szczególnie podatny grunt świadomości narodowej mniejszości pogranicza, przeciwstawiając „zapóźnionym gospodarczo" polskim Kresom Wschodnim fałszywy obraz nowoczesnej gospodarki radzieckiej i systemu sprawiedliwości społecznej. Przenikanie sowieckiej agentury do struktur organizacyjnych podatnego na ideologiczna agitację młodego pokolenia działaczy narodowych pozorowało „wyzwalanie uciśnionych narodów Zachodniej Ukrainy, Zachodniej Białorusi, Górnego Ślaska i Pomorza". Wszelkie tendencje decentralistyczne w dwójnasób wzmacniały antypaństwowe ruchy separatystyczne. Niekwestionowany gwarant zabezpieczenia interesów polskich na pograniczu wschodnim stanowiła zdaniem Baczkowskiego niepodległa Ukraina. W obliczu konfliktu militarnego w Europie Środkowej - uwzględniając rozbieżność celów nacjonalizmu ukraińskiego i imperializmu rosyjskiego (sowieckiego) - zagadnienie sojuszu polsko-ukraińskiego skierowanego przeciwko ZSRR będzie kluczowe. Zagrożenie sowieckie winno być czynnikiem wzmacniającym sojusz polsko-ukraiński i paradoksalnie stanowić remedium dla sanacji na stosunki narodowościowe na Kresach ${ }^{40}$.

\section{Streszczenie}

Uwidoczniony w publicystyce Włodzimierza Baczkowskiego prymat interesów państwa uwarunkowany był zarówno położeniem geopolitycznym, jak i wytworzoną w kręgu tej problematyki „mesjanistyczną myślą narodowa”. Program polityczny ruchu prometejskiego zasadzał się na przeświadczeniu, że zbudowana na przesłankach dyferencjacji Sowietów na państwa narodowe wizja suwerennej Ukrainy zostanie zmaterializowana w nowy podmiot międzynarodowego systemu bezpieczeństwa. W aspekcie materialnego oddziaływania na politykę wschodnią uwypuklał Bączkowski problem zagrożenia niemiecko-rosyjskiego. Przewaga bloku sowiecko-niemieckiego - jego zdaniem - objawiała się w wielu czynnikach: demograficznym, terytorialnym i ekonomicznym (surowcowym). W każdym z tych aspektów sojusznicy Polski ustępowali jej sąsiadom. Przy założeniu, że polska racja stanu nie wiązała się z ekspansją terytorialną na wschodzie, szansy dla wzmocnienia systemu bezpieczeństwa regionalnego upatrywał w możliwości zaistnienia w Europie Środkowej „związku państw małych”. To „sojusz z narodami zniewolonymi” miał zapewnić II Rzeczypospolitej bezpieczne granice. Nawiązując do wspólnoty interesów politycznych, podkreślał Bączkowski znaczenie „względnej identyczności położenia geopolitycznego" narodów polskiego i ukraińskiego. Ubolewał przy tym, że nową kartę w relacjach bilateralnych nadwyrężały skutki traktatu ryskiego i paktu o nieagresji z ZSRR. Zarzucał nacjonalistycznym kołom ukraińskim wykorzystywanie

${ }^{40}$ J.J. Bruski, op. cit., s. 324; K. Grünberg, B. Sprengel, op. cit., s. 351; B. Hud, op. cit., s. 293. 
porozumienia polsko-radzieckiego do podżegania antypolskich nastrojów. Genezy sporu polsko-ukraińskiego nie upatrywał wyłącznie w zaszłościach historycznych. Postrzegał je przede wszystkim „w posunięciach politycznych przywódców narodu polskiego i ukraińskiego”. Podkreślał przy tym, że credo problematyki narodowościowej w Polsce należało rozpatrywać na podstawie formalnego status quo położenia geopolitycznego, gdyż - w jego mniemaniu czynnikiem destabilizującym relacje polsko-ukraińskie „są Niemcy i ZSRR”.

\section{The Geopolitical Imperative of Polish-Ukrainian Cooperation in the Political Thought of the Promethean Movement, on the Example of Włodzimierz Bączkowski's Journalism}

The primacy of the state’s interests reflected in Włodzimierz Bączkowski’s journalism was conditioned by the geopolitical situation, and the "Messianic national thought" developed within this circle. The political programme of the Promethean movement was based on the conviction that the vision of a sovereign Ukraine, built on the premises of the differentiation of the Soviets into nation-states, would materialise into a new entity of the international security system. As regards the material impact on eastern policy, Baczkowski emphasised the problem of the German-Russian threat. In his opinion, the advantage of the Soviet-German bloc manifested itself in several factors: demographic, territorial and economic (raw materials). In each of these aspects, Poland's allies were inferior to its neighbours. Assuming that the Polish raison d'état was not related to the territorial expansion towards the east, he saw an opportunity to strengthen the regional security system in the possibility of the creation of a "union of small states" in Central Europe. The "alliance with enslaved nations" was to provide the Second Republic with secure borders. Referring to the community of political interests, Baczkowski emphasised the importance of the "relative identity of the geopolitical situation" of the Polish and Ukrainian nations. He regretted, however, that the new chapter in bilateral relations was strained by the effects of the Riga Treaty and the non-aggression pact with the USSR. He accused Ukrainian nationalist circles of using the Polish-Soviet agreement to incite anti-Polish sentiments. He did not see the origins of the Polish-Ukrainian dispute solely in the past. He saw it above all "in the political moves of the leaders of the Polish and Ukrainian nations". He stressed at the same time that the ideology of the nationality issue in Poland had to be considered based on the formal status quo of the geopolitical situation because - in his opinion - the factor destabilising the Polish-Ukrainian relations "is Germany and the USSR".

\section{Bibliografia}

Bruski J.J., Między prometeizmem a Realpolitik. II Rzeczpospolita wobec Ukrainy sowieckiej 1921-1926, Kraków 2010.

Chojnowski A., Koncepcje polityki narodowościowej rzqdów polskich w latach 1921-1939, Wrocław 1979.

Cisek J., Świadectwa, „Eurazja” 1997, nr 1, s. 90-91.

Cisek J., Tylko razem. Włodzimierz Baczkowski i „Biuletyn Polsko-Ukraiński”, „Biuletyn Instytutu Pamięci Narodowej” 2008, nr 5/6 (88-89), s. 76-83.

Eberhardt P., Twórcy polskiej geopolityki, Kraków 2006.

Gasimov Z., Między Warszawa, Paryżem a Stambułem. Myśl o prometeizmie w ideowej przestrzeni międzywojennej Europy, w: Ruch prometejski i walka o przebudowę Europy Wschodniej (1918-1940). Studia i szkice, red. M. Kornat, Warszawa 2012, s. 325-340.

Giedroyć J., Włodzimierz Baczkowski, „Eurazja” 1997, nr 1, s. 89. 
Gończyński-Jussis F., Biuletyn Polsko-Ukraiński (1932-1938) - prometejski projekt Oddziału II Sztabu Gtównego Wojska Polskiego, w: Na z góry upatrzonych pozycjach, red. B. Międzybrodzki, M. Gajda, K. Fudalej, M. Przeperski, Warszawa 2011, s. 281-290.

Grünberg K., Sprengel B., Trudne sqsiedztwo. Stosunki polsko-ukrainskie w X-XX wieku, Warszawa 2005.

Hud B., Ukraincy i Polacy na Naddnieprzu, Wotyniu i w Galicji Wschodniej $w$ XIX i pierwszej połowie XX wieku, tłum. A. Korzeniowska-Bihun, M. Hud, Warszawa 2018.

Kloczkowski J., Jak rozwiazać spór polsko-ukrainski? Publicystyka Włodzimierza Baczkowskiego z lat trzydziestych, w: Narody i historia, red. A. Rzegocki, Kraków 2000, s. 207-238.

Libera P., Biuletyn Polsko-Ukraiński (1932-1938) pismo programowe ruchu prometejskiego, „Київські полоністичні студії” 2011, t. XVIII, s. 33-41.

Libera P., Wtodzimierz Baczkowski i jego wspótpraca z paryskq „Kulturq”, w: Giedroyc a Ukraina. Ukrainska perspektywa Jerzego Giedroycia i środowiska paryskiej „Kultury”, red. M. Semczyszyn, M. Zajączkowski, Warszawa-Lublin-Szczecin 2014, s. 104-121.

Maj I.P., Działalność Instytutu Wschodniego w Warszawie 1926-1939, Warszawa 2007.

Maj I.P., Zagadnienie Kresów Wschodnich w myśli politycznej Włodzimierza Bączkowskiego w: Państwo Niepodległe. Twórcy - strategie - komunikacja społeczna, red. A. Dawidowicz, E. Maj, Lublin 2019, s. 31-49.

Materski W., Na widecie. II Rzeczpospolita wobec Sowietów 1918-1943, Warszawa 2005.

Mikulicz S., Prometeizm w polityce II Rzeczypospolitej, Warszawa 1971.

Mironowicz E., Prasa białoruska pod okiem rosyjskiej i polskiej cenzury, „Białoruskie Zeszyty Historyczne" 1996, nr 1 (5), s. 72-85.

Misiło E., Prasa ukrainska w Polsce (1918-1939), „Kwartalnik Historii Prasy Polskiej” 1984, t. XXIII, nr 4, s. 73-84.

Paruch W., Myśl polityczna obozu piłsudczykowskiego, Lublin 2005.

Rutkowski B., Wtodzimierz Baczkowski - publicysta, „Nowy Prometeusz”, IV 2015, nr 7, s. $93-101$.

Szumiło M., Ukraińska Reprezentacja Parlamentarna w Sejmie i Senacie RP (1928-1939), Warszawa 2007.

Szymański K., Tajemnica śmierci Hołówki, „Kurier Galicyjski”, 31 VIII - 11 IX 2017, nr 16 (284), s. 26-27.

Torzecki R., Kwestia ukrainska w Polsce w latach 1923-1929, Kraków 1989.

Werschler I., $Z$ dziejów obozu belwederskiego. Tadeusz Hołówko życie i działalność, Warszawa 1984.

Wiszka E., Prasa emigracji ukraińskiej w Polsce 1920-1939, Toruń 2001.

Zackiewicz G., Polska myśl polityczna wobec systemu radzieckiego 1918-1939, Kraków 2004.

Ireneusz Piotr Maj - dr, adiunkt w Katedrze Historii Polskiej Myśli Politycznej w Instytucie Nauk Politycznych i Stosunków Międzynarodowych Uniwersytetu Jagiellońskiego. Autor publikacji naukowych z zakresu prometeizmu politycznego. Do kręu zainteresowań badawczych autora należą kwestie bezpieczeństwa międzynarodowego w polskiej polityce wschodniej, stosunki polsko-rosyjskie oraz polska myśl sowietologiczna. E-mail: ireneusz.maj@uj.edu.pl.

Ireneusz Piotr Maj - PhD, assistant professor at the Chair in the History of Polish Political Thought at the Institute of Political Science and International Relations of the Jagiellonian University. Author of scientific publications on political Prometheism. His research interests include issues of international security in Polish eastern policy, Polish-Russian relations, and Polish Sovietological thought. E-mail: ireneusz.maj@uj.edu.pl. 
Joanna Maj - dr, adiunkt w Katedrze Historii Polski i Świata po 1945 r. w Instytucie Historii Uniwersytetu Łódzkiego. Do zainteresowań badawczych autorki należą dzieje orientalistyki polskiej i polska myśl wschodoznawcza. E-mail: joanna.maj@uni.lodz.pl.

Joanna Maj - PhD, assistant professor at the Department of History of Poland and World after 1945 at the Institute of History of the University of Łódź. Her research interests include the history of Polish oriental studies and Polish thought on Eastern studies. E-m a il: joanna.maj@uni.lodz.pl. 